\title{
SGK1 inhibitor reverses hyperglycemia partly through decreasing glucose absorption
}

\author{
Ping Li*, Yan Hao*, Feng-Hui Pan*, Min Zhang, Jian-Qiang Ma and Da-Long Zhu \\ Department of Endocrinology, Drum Tower Hospital Affiliated to Nanjing University Medical School, \\ Nanjing, People's Republic of China \\ *( $\mathrm{P} \mathrm{Li}, \mathrm{Y}$ Hao and F-H Pan contributed equally to this work)
}

Correspondence should be addressed to D-L Zhu

Email

zhudalong@nju.edu.cn

\begin{abstract}
This study investigates the effectiveness and mechanisms of a serum- and glucocorticoidinducible kinase 1 (SGK1) inhibitor in counteracting hyperglycemia. In an in vivo experiment, we demonstrated that after an 8-week treatment with an SGK1 inhibitor, the fasting blood glucose and HbA1c level significantly decreased in $d b / d b$ mice. RT-PCR and western blot analyses revealed that intestinal SGK1 and sodium glucose co-transporter 1 (SGLT1) expression were enhanced in $d b / d b$ mice. Treatment with an SGK1 inhibitor decreased excessive SGLT1 expression in the intestine of $d b / d b$ mice. In vitro experiments with intestinal IEC-6 cells showed that the co-administration of an SGK1 inhibitor partly reversed the SGLT1 expression and glucose absorption that were induced by dexamethasone. In conclusion, this study revealed that the favorable effect of an SGK1 inhibitor on hyperglycemia is partly due to decreased glucose absorption through SGLT1 in the small intestine. These data collectively suggest that SGK1 may be a potent target for the treatment of diabetes and other metabolic disorders.
\end{abstract}

\author{
Key Words \\ - serum- and \\ glucocorticoid-inducible \\ kinase 1 (SGK1) \\ - small intestine \\ - IEC-6 intestinal cells \\ - sodium glucose co- \\ transporter 1 (SGLT1)
}

\section{Introduction}

The serum- and glucocorticoid-inducible protein kinase1 (SGK1) is the newest member of the AGC kinases, initially characterized in rat mammary tumor cells as an immediate early gene induced by serum and glucocorticoids (Webster et al. 1993). SGK1 is ubiquitously expressed and participates in the regulation of transport, hormone release, neuroexcitability, cell proliferation, and apoptosis (Lang et al. 2006). The expression of SGK1 is usually low; however, it dramatically increases under certain pathophysiological conditions, such as glucocorticoid or mineralocorticoid excess, hyperglycemia, cell shrinkage, and ischemia (Lang \& Voelkl 2013).

Various functions of SGK1 have been identified (Salker et al. 2011, Borst et al. 2012, Das et al. 2012, Hall et al. 2012). Compelling evidence indicates a role for SGK1 in the development of metabolic syndrome (Lang et al. 2009, Lang \& Voelkl 2013). SGK1 upregulates blood pressure, fosters the development of obesity and type 2 diabetes, and augments platelet activation, all key features of metabolic syndrome (Lang \& Voelkl 2013). A certain variant of the $S G K 1$ gene (the combined presence of distinct polymorphisms in intron 6 (I6CC) and exon 8 (E8CC/CT)) has been shown to be associated with increased blood pressure (Busjahn et al. 2002, von Wowern et al. 2005), obesity, and type 2 diabetes mellitus (Dieter et al. 2004, Schwab et al. 2008).

The mechanism linking SGK1 with hypertension is well documented. SGK1 stimulates renal tubular salt reabsorption and salt appetite; thus, it impacts blood pressure (Lang et al. 2006). SGK1 inhibitors have been developed and shown to reduce blood pressure in hyperinsulinemic mice but not in $S g k 1$-knockout mice (Ackermann et al. 2011). The relationship between SGK1 and diabetes is based on the evidence that SGK1 http://jme.endocrinology-journals.org DOI: 10.1530/JME-15-0285
(C) 2016 Society for Endocrinology Printed in Great Britain 
contributes to the development of obesity (Lang et al. 2009). A previous study on Xenopus oocytes demonstrated that heterologously expressed overactivity of SGK1 enhanced the activity of the sodium glucose co-transporter 1 (SGLT1), which serves to absorb intestinal glucose (Dieter et al. 2004). The accelerated glucose absorption could, at least in theory, lead to a more rapid increase in the plasma glucose concentration, an excessive release of insulin, and a subsequent stimulation of lipid deposition in fat tissue (Lang et al. 2009). This process could eventually potentiate the development of hyperglycemia and diabetes. Conversely, inhibitors of SGLT1 have been shown to counteract obesity (Wagman $\&$ Nuss 2001).

Currently, nothing is known about how these in vitro observations translate into the physiological and pathological regulation of intestinal function. There is no direct evidence to confirm the role of intestinal SGK1-SGLT1 in the development of obesity and hyperglycemia. Our previous study demonstrated enhanced SGK1 expression in the kidney, intestine, and adipose tissue of subjects with obesity and diabetes (Li et al. 2013). This study was performed to explore the effect of SGK1 inhibitors on metabolic disorders in obese and diabetic mice. Furthermore, we focused on intestinal tissue to determine whether the favorable effect of an SGK1 inhibitor on hyperglycemia is partly due to decreased glucose absorption through SGLT1 in the small intestine.

\section{Materials and methods}

\section{Materials}

Insulin, dexamethasone, and 3-isobutyl-1methylxanthine were purchased from Sigma. EMD638683 was provided by Wuxi App Tec Co., Ltd. (Tianjin, China). The inhibitory effect of EMD638683 on SGK1 was tested in vitro by Shang Hai Chempartner Co., Ltd. (Shanghai, China). The rabbit monoclonal antibody against SGK1 was obtained from Cell Signaling Technology. The rabbit polyclonal antibody against SGLT1 was purchased from Merck Millipore. 2-NBDG (2-(N -(7-nitrobenz-2-oxa-1,3diazol-4-yl)amino)-2-deoxyglucose) was obtained from Invitrogen.

\section{Animal procedures}

Male obese 8-week-old $d b / d b$ (BKS.Cg-m+/+Leprdb/NJU-/-) mice and their lean control male $d b / m$ heterozygous littermates were purchased from the Model Animal
Research Center of Nanjing University (Nanjing, China). The mice were maintained on a $12 \mathrm{~h}$ light: $12 \mathrm{~h}$ darkness cycle and were fed a standard laboratory diet and water in a room that was controlled for temperature $\left(23 \pm 3^{\circ} \mathrm{C}\right)$ and humidity $(55 \pm 15 \%)$. $d b / d b$ mice received either no drug treatment $(n=8)$ or the SGK1 inhibitor $(n=8)$ EMD638683 via chow (4.46 mg EMD638683/g chow) for 8 weeks starting at 10 weeks of age. The dosage of EMD638683 was determined by referring several reports (Ackermann et al. 2011, Towhid et al. 2013). Age-matched $d b / m$ mice $(n=8)$ were used as controls in all the experiments.

Body weight was obtained every week from 10 to 18 weeks of age. Food intake and fasting blood glucose were monitored every 2 weeks. HbA1c level was checked at 4 and 8 weeks after intervention using glycosylated hemoglobin analyzer A1CNow + monitor (Bayer HealthCare LLC, Sunnyvale, CA, USA). Systolic blood pressure was measured in conscious animals using a tail-cuff blood pressure analyzer (BP-98A; Softron Corporation, Japan) every 2 weeks. To estimate glucose tolerance, at 17 weeks of age, mice were fasted for $16 \mathrm{~h}$, and a basal blood sample was collected, followed by an intraperitoneal injection of $\mathrm{D}(+)$-glucose $(0.5 \mathrm{mg} / \mathrm{g}$ of body weight). Blood samples were collected from the tail vein at 30, 60, and 120 min after injection. For the insulin tolerance test, mice were fasted for $12 \mathrm{~h}$, and a basal blood sample was taken, followed by an intraperitoneal injection of human regular insulin (1.5 units/ $\mathrm{kg}$ of body weight, Novolin R; Novo Nordisk). The blood samples were collected from the tail vein at 30, 60, 120, 150, and $180 \mathrm{~min}$ after injection.

Finally, the mice were killed at 18 weeks of age. Blood was collected from the left ventricle and centrifuged, and plasma was stored at $-80^{\circ} \mathrm{C}$ for subsequent analyses. Total cholesterol and triglyceride concentrations were measured by an autoanalyzer (Wako). The proximal intestinal segments (from the pylorus to $14-15 \mathrm{~cm}$ above the ileocecal junction) were harvested. Specific tissue samples were either processed for brush-border membrane vesicles (BBMV) preparation, as described later, or rapidly frozen in liquid nitrogen. The tissue samples were stored at $-80^{\circ} \mathrm{C}$ for subsequent RNA and western blot analyses. The Institutional Animal Care and Use Committee of Nanjing University approved our experimental procedures.

\section{IEC-6 cell culture}

Rat intestinal epithelial (IEC-6) cells were obtained from the Cell Resource Center of Peking Union medical school.

Published by Bioscientifica Ltd 
A



D

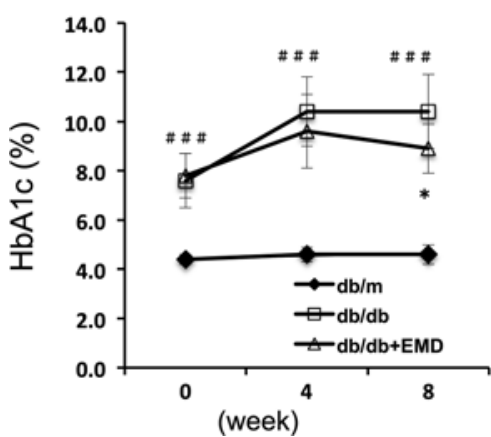

B

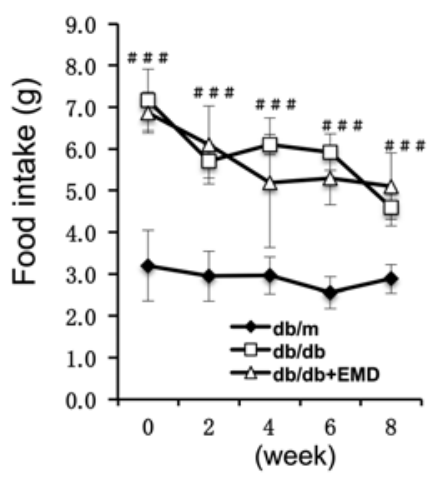

E

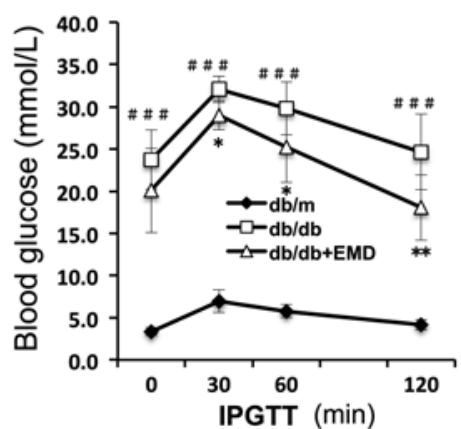

C

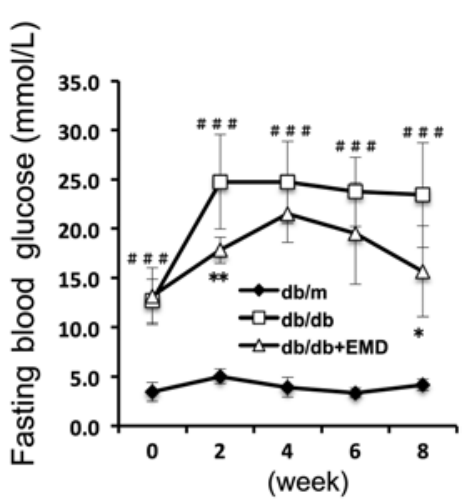

$\mathbf{F}$

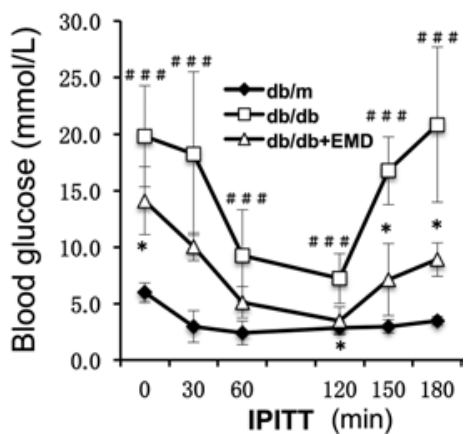

Figure 1

Effects of an SGK1 inhibitor on hyperglycemia in $d b / d b$ mice. $D b / d b$ mice were fed chow containing either no compound ( $d b / d b$ group, $\mathrm{db} / \mathrm{db}$ ) or EMD638683 at $4.46 \mathrm{mg} / \mathrm{g}$ of chow ( $d b / d b+E M D$ group, $\mathrm{db} / \mathrm{db}+\mathrm{EMD}$ ) from 10 weeks of age. $\mathrm{Db} / \mathrm{m} \mathrm{mice}$ served as the control ( $d b / \mathrm{m}$ group, db/m). The body weight was obtained every week from 10 to 18 weeks of age. The food intake, fasting blood glucose, and systolic blood pressure were measured every 2 weeks. The HbA1c level was checked at 4 and 8 weeks after intervention. Glucose and insulin tolerance tests were performed at 17 and 18 weeks of age respectively. (A) Body weight. (B) Food intake. (C) Fasting blood glucose. (D) HbA1C. (E) Plasma glucose curves under the glucose tolerance tests. (F) Plasma glucose curves under the insulin tolerance tests. The data are presented as the mean \pm s.D., $n=8$ mice per group. \#\#\# $P<0.001$ vs control group of $d b / m$ mice. ${ }^{\star} P<0.05 ;{ }^{* \star} P<0.01$ vs control group in $d b / d b$ mice.

IEC-6 cells were maintained in Dulbecco's modified Eagle's medium (containing $4.5 \mathrm{~g} / \mathrm{L}$ glucose) with $10 \%$ fetal calf serum, 5\% heat-inactivated fetal bovine serum (FBS; Gibco), $10 \mathrm{IU} / \mathrm{mL}$ penicillin G, $100 \mu \mathrm{g} / \mathrm{mL}$ streptomycin sulfate, and $10 \mathrm{mg} / \mathrm{L}$ of insulin. Before $24 \mathrm{~h}$ of treatment, the IEC- 6 cells were incubated in a standard medium containing 1\% heat-inactivated FBS. At the time of treatment, the cells were incubated with dexamethasone $(10 \mu \mathrm{M})$ or dexamethasone $(10 \mu \mathrm{M})$ plus the SGK1 inhibitor EMD638683 $(50 \mu \mathrm{M})$. The cells were harvested for RNA and protein analyses after different incubation time points.

\section{Quantitative real-time PCR}

The total RNA was extracted from whole tissue samples and IEC-6 cells using Trizol reagent according to the manufacturer's instructions. Briefly, $2 \mu \mathrm{g}$ of total RNA was

reverse transcribed into cDNA using random primers and SuperScript II reverse transcriptase (Invitrogen). The gene expression was analyzed using relative quantification with the

Table 1 Effects of the SGK1 inhibitor EMD638683 on metabolic and physiologic parameters in $d b / d b$ mice.

\section{Ba}

Body weight $(g)$

Food intake (g)

Mean SBP

$(\mathrm{mmHg})$

Plasma glucos

( $\mathrm{mmol} / \mathrm{L})$

HbA1c (\%)

Triglyceride

( $\mathrm{mmol} / \mathrm{L})$

Total cholesterol (mmol/L)

\begin{tabular}{c}
$\mathbf{d b} / \mathbf{m}$ \\
\hline $21.8 \pm 0.8$ \\
$2.9 \pm 0.3$ \\
$118.1 \pm 6.0$
\end{tabular}

$5.3 \pm 1.9 \quad 29.3 \pm 7.6^{\# \#}$

$4.6 \pm 0.1 \quad 10.4 \pm 1.5^{\# \#}$

$0.8 \pm 0.18 \quad 1.5 \pm 0.4 \# \#$

$1.8 \pm 0.2$

$3.9 \pm 0.5^{\# \#}$

$2.9 \pm 0.1^{*}$

$\# P<0.05,{ }^{\#} P<0.01$ vs $d b / m$ mice, ${ }^{*} P<0.05$ vs $d b / d b$ mice. $\mathrm{SBP}$, systolic BP. 
${ }^{2}{ }^{-} \triangle$ Ct method using real-time PCR with an ABI Prism 7300 instrument (Applied Biosystems). Real-time PCR was performed in 96-well plates using SYBR Premix Ex Taq (Takara, Shiga, Japan) according to the supplier's instructions. All the samples were normalized to values of $\beta$-actin, and the results are expressed as fold-changes of the threshold cycle $(\mathrm{Ct})$ value relative to the controls. The cycling parameters were $95^{\circ} \mathrm{C}$ for $10 \mathrm{~s}, 40$ cycles of $95^{\circ} \mathrm{C}$ for $5 \mathrm{~s}$, and $60^{\circ} \mathrm{C}$ for $31 \mathrm{~s}$. The quantifications were performed in quadruplicate, and the experiments were independently repeated three times. The following primers were used: rat $\beta$-actin: FP, 5'-TCACCAACTGGGACGATA-3'; and RP, 5'-AGGCATACAGGGACAACA-3'; rat $S g k 1$ : FP, 5'-CAGAATGAGGGGAATGGTAGC-3' and RP, 5'-AGAGGGACTTGGAGGAGGTG-3'; rat Sglt1: FP, 5'-GCCCTTTACACCATCACA-3' and RP, 5'-GCCTCATACCCTCCTACTTCT-3'; mouse $\beta$-actin: FP, 5'-TGTGACGTTGACATCCGTAAAGAC-3' and RP, 5'-TCCACACAGAGTACTTGCGCTC-3'; mouse Sgk1: FP, 5'-TGAGATGCTCTACGGCCTGC-3' and RP, 5'-CTCTTGGTCCGGTCCTTCTG-3'; and mouse Sglt1: FP, 5'-GTGGCTTTGAATGGAACGC-3' and RP, 5'-CAAACCGCTTCCGCAGAT-3' .

\section{Preparation of mouse intestinal brush-border membrane vesicles}

Crude BBMV were obtained according to the method described by Kessler et al. (1978), with some modifications. BBMV were prepared from IEC- 6 cells and a piece of small intestine taken from every animal in each group. The mucosa was re-suspended in a buffer consisting of $300 \mathrm{mM}$ mannitol adjusted to $\mathrm{pH} 7.1$ with Tris. The suspension was then homogenized at $10,000 \mathrm{rpm}$ at $4^{\circ} \mathrm{C}$ for $1 \mathrm{~min}$. Next, $1 \mathrm{M} \mathrm{MgCl}_{2}$ was added to a final concentration of $10 \mathrm{mM}$, and the mixture was incubated on ice with continuous ice-cold shaking for $20 \mathrm{~min}$. The mixture was then centrifuged at $3000 \boldsymbol{g}$ for $15 \mathrm{~min}$, and the supernatant was collected. After letting the supernatant stand for $15 \mathrm{~min}$, it was finally centrifuged at 30,000 $\boldsymbol{g}$ for $30 \mathrm{~min}$. The supernatant was discarded, the pellet was re-suspended in the same buffer consisting of $300 \mathrm{mM}$ mannitol, and the centrifugation at 30,000 $\boldsymbol{g}$ for $30 \mathrm{~min}$ was repeated. The final pellet, containing the purified BBMV, was homogenized by passing the suspension through 25-gauge needles and was solubilized in a buffer consisting of $50 \mathrm{mM}$ mannitol. All the steps were carried out at $4^{\circ} \mathrm{C}$. After the final suspension, the samples were frozen at $80^{\circ} \mathrm{C}$ for later use.

\section{Western blot analysis}

The expression of transporters SGLT1 in BBMV and SGK1 from mouse small intestinal tissue and rat IEC-6 cell lysates were detected using western blot, as described previously ( $\mathrm{Li}$ et al. 2013). The protein samples were loaded onto $12 \%$ SDS-PAGE gels and transferred onto nitrocellulose membranes following standard procedures.
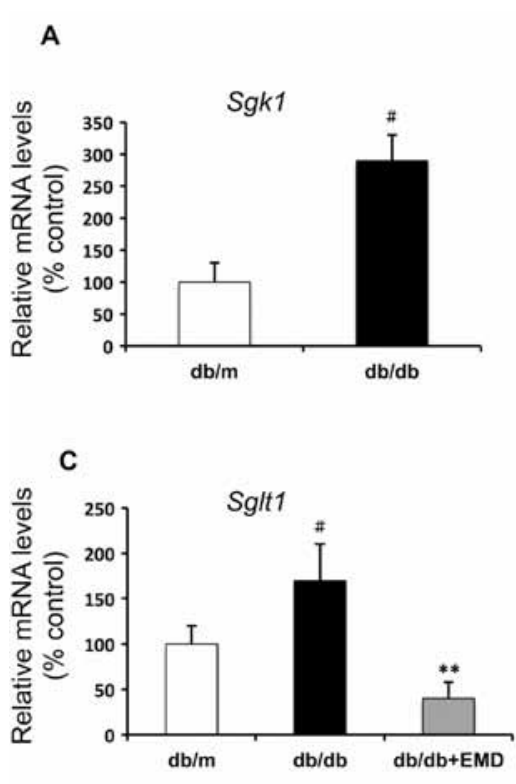

http://jme.endocrinology-journals.org DOI: $10.1530 / \mathrm{JME}-15-0285$
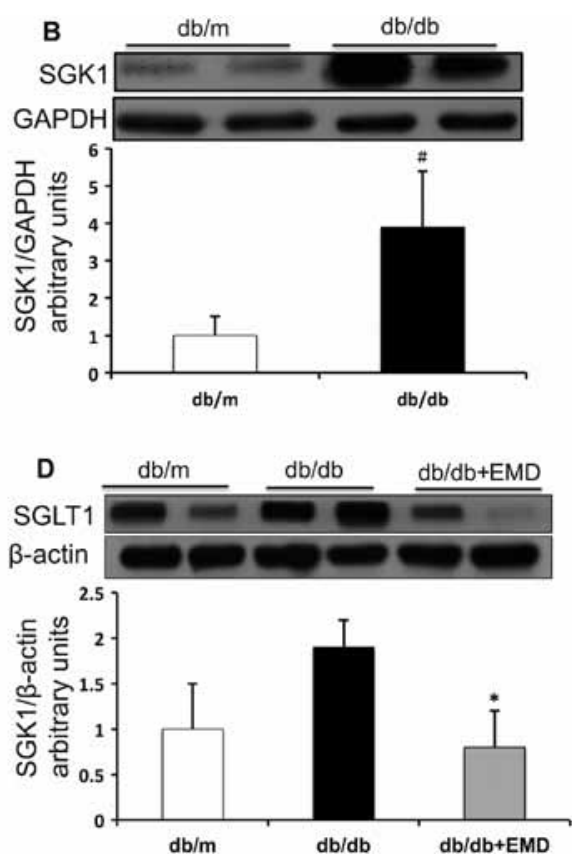

Figure 2

Effects of an SGK1 inhibitor on intestinal SGLT1 expression in $d b / d b$ mice. Mice were fed chow containing either no compound ( $d b / m$ group, $\mathrm{db} / \mathrm{m} ; \mathrm{db} / \mathrm{db}$ group, $\mathrm{db} / \mathrm{db}$ ) or EMD638683 at $4.46 \mathrm{mg} / \mathrm{g}$ of chow $(\mathrm{db} / \mathrm{d} b+\mathrm{EMD}$ group, $\mathrm{db} / \mathrm{db}+\mathrm{EMD}$ ) from 10 weeks of age, and intestinal tissue was excised at 18 weeks of age and analyzed. (A and B) SGK1 mRNA (A) and protein (B) levels in intestinal tissue from $\mathrm{db} / \mathrm{db}$ and control $d b / m$ mice. (C and D) SGLT1 mRNA (C) and protein (D) levels in intestinal tissue from $d b / m, d b / d b$, and $d b / d b+E M D$ mice. The total RNA was isolated from intestinal tissue, and first-strand CDNA was synthesized as described in the Methods section. Real-time quantitative PCR was performed, and the values were normalized to the level of $\beta$-actin mRNA. Protein was extracted from the intestinal tissue and subjected to western blot analysis. The relative protein levels were normalized to the GAPDH or $\beta$-actin protein level. The bands were quantified through densitometry using the Quantity One system. The results (means \pm S.D.) are expressed as the fold change relative to the levels of the $\mathrm{db} / \mathrm{m}$ group (Con, $100 \%$ or 1 ). ${ }^{\#} P<0.05$ vs control group of $d b / m$ mice. ${ }^{*} P<0.05 ;{ }^{* \star} P<0.01$ vs control group in $d b / d b$ mice. 
The membranes were incubated with a rabbit antiSGK1 primary antibody (1:500) or an anti-SGLT1 primary antibody (1:500) overnight at $4-8^{\circ} \mathrm{C}$, followed by incubation with horseradish peroxidaseconjugated secondary antibodies for at least $1 \mathrm{~h}$ at room temperature. Detection was carried out using enhanced chemiluminescence reagents according to the manufacturer's protocol (Amersham Pharmacia).

\section{Glucose uptake measurement using flow cytometry}

The glucose uptake assay using the 2-NBDG screening system was performed as described previously (Zhang et al. 2010). Briefly, IEC-6 cells were seeded at $1 \times 10^{4}$ cells/well into 96-well plates for $24 \mathrm{~h}$ and then treated with or without a given concentration of dexamethasone and $50 \mu \mathrm{M}$ of the SGK1 inhibitor EMD638683 in the absence or presence of $100 \mu \mathrm{M} 2$-NBDG for $1 \mathrm{~h}$. The fluorescence intensity of 2-NBDG was recorded in the FL1 channel using a FACScaanto TM flow cytometer (Becton Dickinson, Franklin Lakes, NJ, USA). To rule out falsepositives, drug treatment in the absence of 2-NBDG was measured and considered as the background. The relative fluorescence intensities minus the background levels were used for the data analysis.

\section{Statistical analysis}

The results were reproduced in at least three independent experiments. The results are presented as the means \pm s.D. Significance was determined by Student's t-test or one-way ANOVA. In all the statistical comparisons, a $P$ value $<0.05$ was considered statistically significant.

\section{Results}

\section{Effects of an SGK1 inhibitor on hyperglycemia in $d b / d b$ mice}

The body weight of $d b / d b$ mice dramatically increased throughout the entire period of the experiment compared with that of nondiabetic $d b / m$ mice $(P<0.001$, Fig. $1 \mathrm{~A})$. A significant decrease was detected in the body weights of $d b / d b$ mice after 5 weeks of treatment with the SGK1 inhibitor EMD638683 until the end of the experiment $(P<0.01$; Table 1 and Fig. $1 \mathrm{~A})$. There was no difference in
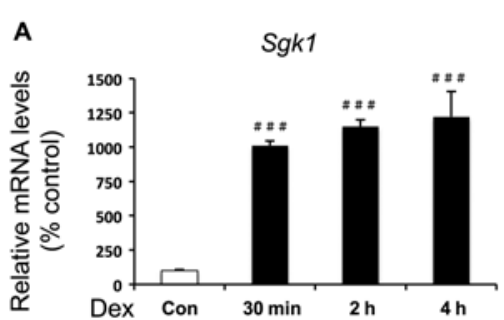

C
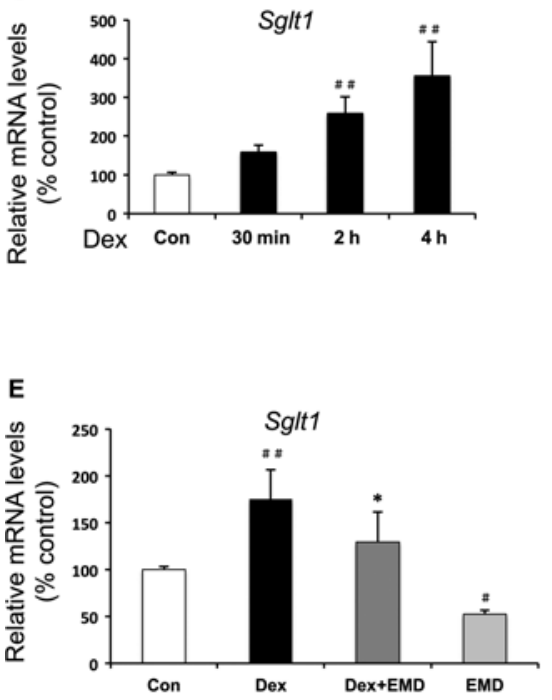

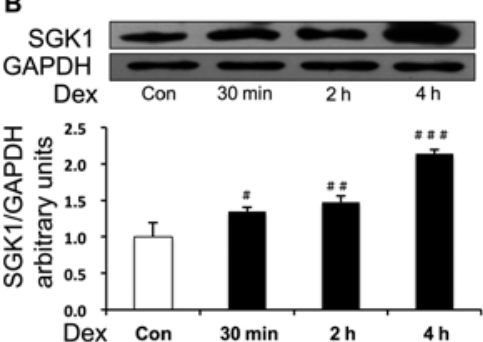

D
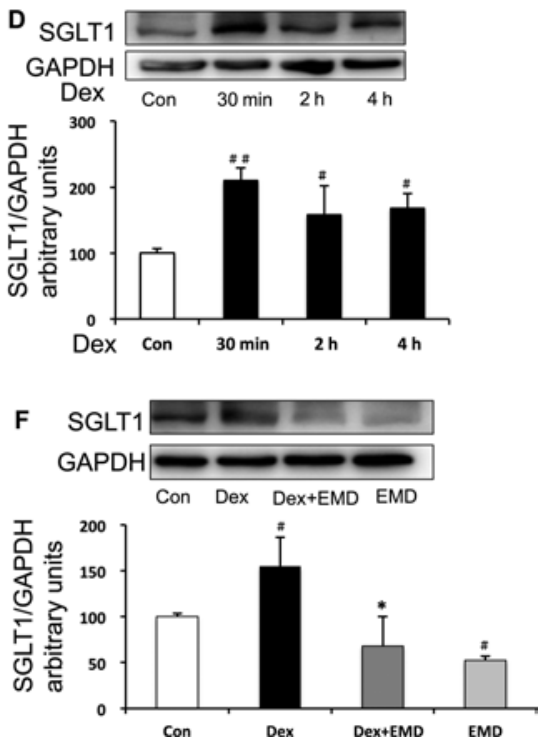

Figure 3

Effects of an SGK1 inhibitor on SGLT1 expression in IEC-6 cells. IEC-6 cells were serum deprived overnight before dexamethasone and/or the SGK1 inhibitor (EMD638683, EMD) was added. ( $A$ and $B$ ) SGK1 mRNA (A) and protein (B) expression in dexamethasone (Dex)-treated IEC-6 cells. (C and D) Sglt1 mRNA (C) and protein (D) expression in Dex-treated IEC-6 cells. (E and F) Sglt1 mRNA $(E)$ and protein $(F)$ expression in Dex- and EMD-treated IEC- 6 cells. The total RNA was extracted, and real-time quantitative PCR was performed. The relative mRNA levels were normalized to $\beta$-actin mRNA expression. The protein was extracted from IEC- 6 cells and subjected to western blot analysis. The bands were quantified by densitometry using the Quantity One system. The results (means \pm S.D.) are expressed as the fold change relative to the levels of the control group (Con, $100 \%$ or 1 ). ${ }^{\#} P<0.05$; $\# P<0.01 ; \# \# P<0.001$ vs untreated control cells; ${ }^{\star} P<0.05$ vs Dex-treated cells. 
A

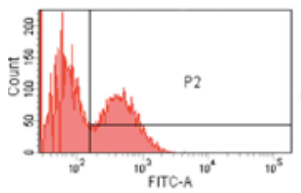

Con

B
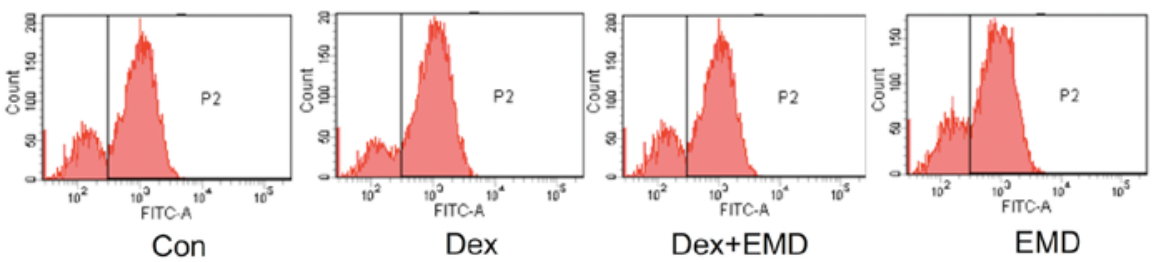
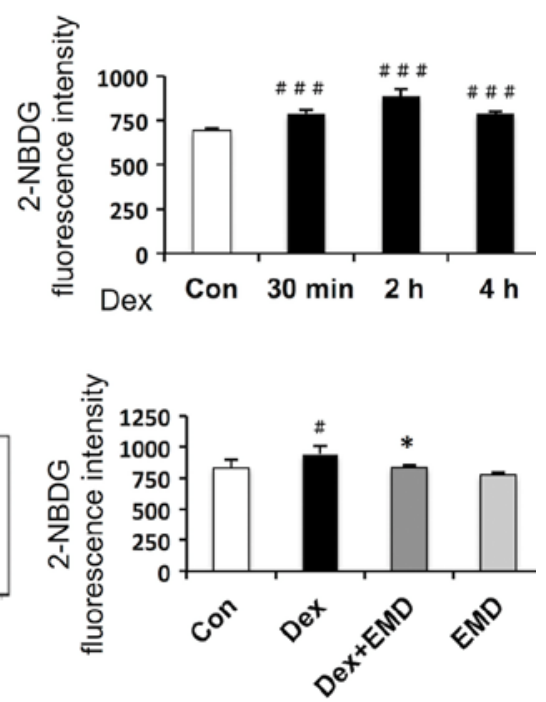

\section{Figure 4}

Effects of an SGK1 inhibitor on glucose absorption in IEC-6 cells. IEC-6 cells were serum deprived overnight before dexamethasone and/or the SGK1 inhibitor (EMD638683, EMD) was added. (A) Representative data and quantification of the glucose absorption by flow cytometry in Dex-treated IEC-6 cells. (B) Representative data and quantification of the glucose absorption by flow cytometry in Dex- and EMD-treated IEC-6 cells. A glucose uptake assay using the 2-NBDG screening system was performed as described in the Materials and Methods section. The fluorescence intensities in the absence of 2-NBDG were measured and considered as the background. The relative fluorescence intensities minus the background levels were used for the data analysis. Values are means \pm S.D. of three replicates in four separate experiments. $\# P<0.05 ; \# \# P<0.001$ vs untreated control cells; ${ }^{\star} P<0.05$ vs Dex-treated cells. A full color version of this figure is available at http://dx.doi.org/10.1530/JME-15-0285.

food intake between $d b / d b$ mice that were treated with or without EMD638683 (Table 1 and Fig. 1B).

Diabetic $d b / d b$ mice exhibited dramatically increased fasting blood glucose and HbA1c levels compared with those of the nondiabetic $d b / m$ mice $(P<0.001$; Table 1 , Fig. $1 \mathrm{C}$ and D). The fasting blood glucose was decreased and become significant at 2 and 8 weeks after EMD638683 treatment compared with the control $d b / d b$ mice $(P<0.01$ and $P<0.05$, respectively; Fig. $1 \mathrm{C}$ ). The HbA1c levels were reduced at 4 weeks and were significantly lower at the end of the experiment than in the control $d b / d b$ mice $(P<0.05$; Table 1 and Fig. 1D).

The glucose tolerance test demonstrated that EMD638683 treatment significantly suppressed an elevation in plasma glucose after glucose infusion in $\mathrm{db} /$ $d b$ mice $(P<0.01$ and $P<0.05$, respectively; Fig. $1 \mathrm{D}$ and $\mathrm{E})$. In the insulin tolerance test, the plasma glucose level of the EMD638683 group tended to be reduced at $15 \mathrm{~min}$ and was significantly lower at 120, 150, and $180 \mathrm{~min}$ after insulin injection than those of the control group $(P<0.05$, Fig. 1F).

The treatment of $d b / d b$ mice for 8 weeks with EMD638683 also significantly reduced the systolic blood pressure and the plasma triglyceride and cholesterol levels compared with the $d b / d b$ control group $(P<0.05$, respectively; Table 1 ).

\section{Effects of an SGK1 inhibitor on intestinal SGLT1 expression in $d b / d b$ mice}

Sgk1 mRNA expression in the intestinal tissue of $d b / d b$ mice was higher than in the $d b / m$ mice (Fig. 2A). We further confirmed excessive intestinal SGK1 expression at the protein level in $d b / d b$ mice (Fig. 2B).

SGLT1 is highly expressed on the brush-border membrane of villus enterocytes in the proximal part of the small intestine and is responsible for dietary glucose absorption. We examined intestinal SGLT1 mRNA and protein expression in $d b / d b$ mice. Compared with $d b / m$ mice, $d b / d b$ mice exhibited enhanced intestinal SGLT1 mRNA and protein expression (Fig. 2C and D). Treatment with the SGK1 inhibitor for 8 weeks significantly reduced intestinal SGLT1 mRNA and protein expression in $d b / d b$ mice (Fig. 2C and D).

\section{Effects of SGK1 inhibitor on SGLT1 expression and glucose absorption in IEC-6 cells}

Dexamethasone treatment resulted in a time-dependent increase in SGK1 mRNA and protein expression in rat small intestinal cell lines (IEC-6 cells) (Fig. 3A and B). Simultaneously, dexamethasone enhanced Sglt1 mRNA and protein expression in a time-dependent manner

Published by Bioscientifica Ltd 
(Fig. 3C and D). We additionally performed glucose uptake assays using the 2-NBDG screening system. As suspected, dexamethasone also promoted glucose uptake in IEC-6 cells (Fig. 4A). Co-administration of SGK1 inhibitor decreased the Sglt1 expression and glucose absorption that was induced by dexamethasone (Figs 3E, F and B). In addition, SGK1 inhibitor alone decreased Sglt1 expression but did not affect glucose absorption in IEC-6 cells (Figs 3E, F and B).

\section{Discussion}

The role of SGK1 in the development of metabolic syndrome is an interesting and vital topic that has not been fully elucidated. This study clearly showed that (1) an SGK1 inhibitor ameliorated obesity and hyperglycemia in $d b / d b$ mice; (2) intestinal SGK1 and SGLT1 expression are enhanced in obese and diabetic $d b / d b$ mice. Treatment with an SGK1 inhibitor decreased excessive intestinal SGLT1 expression in $d b / d b$ mice; (3) in intestinal IEC-6 cells, the co-administration of an SGK1 inhibitor partly reverses the SGLT1 expression and glucose absorption induced by dexamethasone. This study reveals that an SGK1 inhibitor reverses hyperglycemia in $d b / d b$ mice partly through decreasing glucose absorption in the small intestine.

This study is the first to demonstrate that the pharmacological inhibition of SGK1 counteracts hyperglycemia in vivo. Of note, both the fasting blood glucose and the HbA1c confirmed the hypoglycemic effect of an SGK1 inhibitor in $d b / d b$ mice. The effect of weight loss due to an SGK1 inhibitor was observed in a previous study after a 4-day treatment, in which the SGK1 inhibitor decreased the blood pressure in fructose/ saline-treated mice (Ackermann et al. 2011). This study confirmed the antihypertensive and weight loss effect of an SGK1 inhibitor in $d b / d b$ mice during the long term. The food intake of the intervention group remained stable throughout the experiment, which ruled out weight loss owing to a decreased appetite. The fasting blood glucose significantly decreased after 1 week of SGK1 inhibitor treatment. However, the body weight of $d b / d b$ mice did not change at that time point, which suggests that the hypoglycemic effect is not completely dependent on weight loss. Furthermore, we detected that the triglyceride and total cholesterol levels also decreased in $d b / d b$ mice after the intervention of SGK1 inhibitor.

SGK1 expression is particularly abundant in the intestine, suggesting a role for the kinase in intestinal transport regulation (Lang et al. 2006). Our group first described that intestinal SGK1 expression is enhanced in obese and diabetic mice (Li et al. 2013). SGLT1 is an intestinal glucose sensor and electrogenic coupler of sodium ions and glucose uptake (Tahrani et al. 2013). Fujita et al. (1998) reported that intestinal glucose absorption through SGLT1 was increased in 6-week-old OLETF rats before the onset of insulin resistance and hyperinsulinemia. An SGLT1 inhibitor has been shown to counteract hyperglycemia and obesity (Wagman \& Nuss 2001). In accordance with previous studies, this study also detected enhanced intestinal SGLT1 expression in $d b / d b$ mice. An excessive expression of SGK1 in Xenopus oocytes described the regulatory effect of SGK1 on SGLT1 (Dieter et al. 2004). SGK1 is a mediator of glucocorticoid-initiated signals in different cells (Ullrich et al. 2005, Di Pietro et al. 2010). Previous studies using Sgk1-knockout mice determined that intestinal SGK1 expression was upregulated by dexamethasone, and the effects of glucocorticoids on SGLT1 were fully dependent on SGK1 (Grahammer et al. 2006). Our study confirmed the regulatory effect of SGK1 on SGLT1 and its role as a mediator of glucocorticoids in rat intestinal IEC- 6 cells.

This study reveals the effectiveness of an SGK1 inhibitor in decreasing intestinal SGLT1 expression and glucose absorption in vivo and in vitro. This effect may be one of the mechanisms by which the SGK1 inhibitor reverses hyperglycemia in $d b / d b$ mice. The SGK1 inhibitor may also transiently inhibit SGLT1 and thereby defer and delay glucose absorption along the distal intestine (Oguma et al. 2015). This effect in itself would help reduce the prandial glucose excursion and might increase GLP1 and peptide YY secretion from intestinal L cells (Oguma et al. 2015). Further study is needed to investigate the effect of SGK1 inhibitors on the secretion of incretin.

Excessive glucocorticoids result in whole-body insulin resistance, obesity, and hyperglycemia (Geer et al. 2014). Metabolic syndrome shares many clinical features with excess glucocorticoid or Cushing's syndrome (Lang et al. 2009). There is speculation that, at least in some individuals, increased glucocorticoid-independent SGK1 expression accounts for metabolic disorders (Lang et al. 2009). SGK1 expression is low in normal tissue, and SGK1-sensitive functions are in large regulated by its isoforms (Lang et al. 2006). Accordingly, the phenotype of the $S g k 1$-knockout mouse is mild (Lang et al. 2006). Thus, specific inhibition of SGK1 expected to have modest side effects and not abrogate housekeeping functions (Lang \& Voelkl 2013). Targeting SGK1 may be a therapeutic option to counteract metabolic disorders.

Published by Bioscientifica Ltd. 
Until now, several SGK1 inhibitors have been developed, including GSK650394, LY294002, SI113, and EMD638683 (Towhid et al. 2013, D’Antona et al. 2015). Compared with others, EMD638683 is the most selective SGK1 inhibitor (Towhid et al. 2013). Moreover, EMD638683 is readily soluble in water and is the first SGK inhibitor shown to be effective in vivo (Ackermann et al. 2011). A newly published study showed that EMD638683 can decrease the number of colonic tumors following chemical carcinogenesis (Towhid et al. 2013). Our study adds new evidence of the effectiveness of EMD638683 in vivo. Additionally, the 12-week treatment with EMD638683 in this study suggests the long-term safety of this inhibitor in mice.

In conclusion, our results add new evidence of the effectiveness of an SGK1 inhibitor in counteracting hyperglycemia and provide novel insights into targeting SGK1 for the treatment of diabetes and other metabolic disorders. Further study is ongoing in our laboratory to investigate non-intestinal tissues that may be involved in the pathological role of SGK1 in hyperglycemia and obesity.

\section{Declaration of interest}

The authors declare that there is no conflict of interest that could be perceived as prejudicing the impartiality of the research reported.

\section{Funding}

This work was supported by the National Natural Science Foundation of China (grant numbers 81000350), Jiangsu Province's Key Discipline of Medicine (XK201105), and Science Fund for Distinguished Young Scholars of Nanjing, China (JQX13010).

\section{References}

Ackermann TF, Boini KM, Beier N, Scholz W, Fuchß T \& Lang F 2011 EMD638683, a novel SGK inhibitor with antihypertensive potency. Cellular Physiology and Biochemistry 28 137-146. (doi:10.1159/000331722)

Borst O, Schmidt EM, Münzer P, Schönberger T, Towhid ST, Elvers M, Leibrock C, Schmid E, Eylenstein A, Kuhl D, et al. 2012 The serumand glucocorticoid-inducible kinase 1 (SGK1) influences platelet calcium signaling and function by regulation of Orai1 expression in megakaryocytes. Blood 119 251-261. (doi:10.1182/blood-2011-06359976)

Busjahn A, Aydin A, Uhlmann R, Krasko C, Bähring S, Szelestei T, Feng Y, Dahm S, Sharma AM, Luft FC, et al. 2002 Serum- and glucocorticoid-regulated kinase (SGK1) gene and blood pressure. Hypertension 40 256-260. (doi:10.1161/01.HYP.0000030153.19366.26)

D'Antona L, Amato R, Talarico C, Ortuso F, Menniti M, Dattilo V, Iuliano R, Gigliotti F, Artese A, Costa G, et al. 2015 SI113, a specific inhibitor of the Sgk1 kinase activity that counteracts cancer cell proliferation. Cellular Physiology and Biochemistry 35 2006-2018. (doi:10.1159/000374008)
Das S, Aiba T, Rosenberg M, Hessler K, Xiao C, Quintero PA, Ottaviano FG, Knight AC, Graham EL, Boström P, et al. 2012 Pathological role of serum- and glucocorticoid-regulated kinase 1 in adverse ventricular remodeling. Circulation 126 2208-2219. (doi:10.1161/CIRCULATIONAHA.112.115592)

Dieter M, Palmada M, Rajamanickam J, Aydin A, Busjahn A, Boehmer C, Luft FC \& Lang F 2004 Regulation of glucose transporter SGLT1 by ubiquitin ligase Nedd4-2 and kinases SGK1, SGK3, and PKB. Obesity Research 12 862-870. (doi:10.1038/oby.2004.104)

Di Pietro N, Panel V, Hayes S, Bagattin A, Meruvr S, Pandolfi A, Hugendubler L, Fejes-Tóth G, Naray-Fejes-Tóth A \& Mueller E 2010 Serum- and glucocorticoid-inducible kinase 1(SGK1) regulates adipocyte differentiation via forkhead box O1. Molecular Endocrinology 24 370-380. (doi:10.1210/me.2009-0265)

Fujita Y, Kojima H, Hidaks H, Fujimiya M, Kashiwagi A \& Kikkawa R 1998 Increased intestinal glucose absorption and postprandial hyperglycaemia at the early step of glucose intolerance in Otsuka Long-Evans Tokushima Fatty Rats. Diabetologia 41 1459-1466. (doi:10.1007/s001250051092)

Geer EB, Islam J \& Buettner C 2014 Mechanisms of glucocorticoidinduced insulin resistance. Focus on adipose tissue function and lipid metabolism. Endocrinology and Metabolism Clinics of North America 43 75-102. (doi:10.1016/j.ecl.2013.10.005)

Grahammer F, Henke G, Sandu C, Rexhepaj R, Hussain A, Friedrich B, Risler T, Metzger M, Just L, Skutella T, et al. 2006 Intestinal function of gene-targeted mice lacking serum-and glucocorticoid-inducible kinase 1. American Journal of Physiology: Gastrointestinal and Liver Physiology 290 G1114-G1123. (doi:10.1152/ajpgi.00231.2005)

Hall BA, Kim TY, Skor MN \& Conzen SD 2012 Serum and glucocorticoid-regulated kinase 1 (SGK1) activation in breast cancer: requirement for mTORC1 activity associates with ER-alpha expression. Breast Cancer Research and Treatment 135 469-479. (doi:10.1007/s10549-012-2161-y)

Kessler M, Acuto O, Storelli C, Murer H, Muller H \& Semenze G 1978 A modified procedure for the rapid preparation of efficiently transporting vesicles from small intestinal brush border membranes: their use in investigating some properties of D-glucose and choline transport systems. Biochimica et Biophysica Acta 506 136-154. (doi:10.1016/0005-2736(78)90440-6)

Lang F \& Voelkl J 2013 Therapeutic potential of serum and glucocorticoid inducible kinase inhibition. Expert Opinion on Investigational Drugs 22 701-714. (doi:10.1517/13543784.2013.778971)

Lang F, Böhmer C, Palmada M, Seebohm G, Strutz-seebohm N \& Vallon V 2006 (Patho)physiological significance of the serum-and glucocorticoid-inducible kinase isoforms. Physiological Reviews $\mathbf{8 6}$ 1151-1178. (doi:10.1152/physrev.00050.2005)

Lang F, Gorlach A \& Vallon V 2009 Targeting SGK1 in diabetes. Expert Opinion on Therapeutic Targets 13 1303-1311. (doi:10.1517/14728220903260807)

Li P, Pan FH, Hao Y, Feng WH, Song HD \& Zhu DL 2013 SGK1 is regulated by metabolic-related factors in 3T3-L1 adipocytes and overexpressed in the adipose tissue of subjects with obesity and diabetes. Diabetes Research and Clinical Practice 102 35-42. (doi:10.1016/j.diabres.2013.08.009)

Oguma T, Nakayama K, Kuriyama C, Matsushita Y, Yoshida K, Hikida K, Obokata N, Tsuda-Tsukimoto M, Saito A, Arakawa K, et al. 2015 Intestinal sodium glucose cotransporter 1 inhibition enhances glucagon-like peptide- 1 secretion in normal and diabetic rodents. Journal of Pharmacology and Experimental Therapeutics 354 279-289. (doi:10.1124/jpet.115.225508)

Salker MS, Christian M, Steel JH, Nautiyal J, Lavery S, Trew G, Webster Z, Al-Sabbagh M, Puchchakayala G, Föller M, et al. 2011 Deregulation of the serum- and glucocorticoid-inducible kinase SGK1 in the endometrium causes reproductive failure. Natural Medicine 17 1509-1513. (doi:10.1038/nm.2498) 
Schwab M, Lupescu A, Mota M, Mota E, Frey A, Simon P, Mertens PR, Floege J, Luft F, Asante-Poku S, et al. 2008 Association of SGK1 gene polymorphisms with type 2 diabetes. Cellular Physiology and Biochemistry 21 151-160. (doi:10.1159/000113757)

Towhid ST, Liu GL, Ackermann TF, Beier N, Scholz W, Fuchß T, Toulany M, Rodemann HP \& Lang F 2013 Inhibition of colonic tumor growth by the selective SGK inhibitor EMD638683. Cellular Physiology and Biochemistry 32 838-848. (doi:10.1159/000354486)

Ullrich S, Berchtold S, Ranta F, Seebohm G, Henke G, Lupescu A, Mack AF, Chao CM, Su J, Nitschke R, et al. 2005 Serum- and glucocorticoid-inducible kinase 1 (SGK1) mediates glucocorticoidinduced inhibition of insulin secretion. Diabetes 54 1090-1099. (doi:10.2337/diabetes.54.4.1090)

von Wowern F, Berglund G, Carlson J, Månsson H, Hedblad B \& Melander O 2005 Genetic variance of SGK-1 is associated with blood pressure, blood pressure change over time and strength of the insulin-diastolic blood pressure relationship. Kidney International 68 2164-2172. (doi:10.1111/j.1523-1755.2005.00672.x)

Wagman AS \& Nuss JM 2001 Current therapies and emerging targets for the treatment of diabetes. Current Pharmaceutical Design 7 417-450. (doi:10.2174/1381612013397915)

Webster MK, Goya L, Ge Y, Maiyar AC \& Firestone GL 1993 Characterization of sgk, a novel member of the serine/threonine protein kinase gene family which is transcriptionally induced by glucocorticoids and serum. Molecular and Cellular Biology 13 2031-2040. (doi:10.1128/MCB.13.4.2031)

Zhang WY, Lee JJ, Kim IS, Kim Y, Park JS \& Myung CS 2010 7-O-Methylaromadendrin stimulates glucose uptake and improves insulin resistance in vitro. Biological and Pharmaceutical Bulletin 33 1494-1499. (doi:10.1248/bpb.33.1494)

Received in final form 15 February 2016

Accepted 23 February 2016

Accepted Preprint published online 23 February 2016
C 2016 Society for Endocrinology Printed in Great Britain
Published by Bioscientifica Ltd. 